\title{
Estrogen receptor alpha mediates neuronal differentiation and neuroprotection in PC12 cells: critical role of the A/B domain of the receptor
}

\author{
Yohann Mérot, François Ferrière, Edith Debroas ${ }^{1}$, Gilles Flouriot, Dominique Duval ${ }^{1}$ and \\ Christian Saligaut
}

CNRS UMR 6026-Endocrinologie Moléculaire de la Reproduction, Université de Rennes 1, campus de Beaulieu, 35042 Rennes cedex, France

${ }^{1}$ CNRS UMR 6185- Université de Caen, INSERM-Avenir "tPA in the working brain" Centre Cycéron, BP 5229, 14074 Caen cedex, France

(Requests for offprints should be addressed to C Saligaut; Email: Christian.saligaut@univ-rennes1.fr)

\begin{abstract}
Numerous studies, both in vivo and in vitro, have reported neuronal differentiating and neuroprotective actions of estrogens. Most of these estrogenic effects are mediated through specific receptors termed estrogen receptors. The aim of this study was to assess the importance of the N-terminal A/B domain of the estrogen receptor-alpha (ER $\alpha)$ in its neuronal aspects. Consequently, estrogen effects on (i) the transcriptional activity of target genes, (ii) neuronal differentiation and (iii) neuroprotection in PC12 cells transfected with either a full length form of $E R \alpha$ or an $A / B$ domain truncated form (ER $\alpha \mathrm{CF})$, have been studied. We demonstrate that the maximal estrogen-induced transcriptional activity of reporter genes requires a full length $E R \alpha$, especially when cells are differentiated. Precisely, the transcriptional activity of ER $\alpha$ in differentiated cells relies, predominantly, on the activation function AF-1, located in the $\mathrm{A} / \mathrm{B}$ domain. Furthermore, in PC12 cells stably expressing $\mathrm{ER} \alpha, 17 \beta$-estradiol markedly enhances the neurite outgrowth triggered by treatment with nerve growth factor and protects cells from oxidative shocks induced by depletion of glutathione. These estrogenic effects are not observed in non-transfected cells and in cells transfected with the truncated $E R$, devoid of the $A / B$ domain. Altogether, these results underline the importance of the $A / B$ domain of $\mathrm{ER} \alpha$ in both the differentiating and the neuroprotective effects of estrogens.
\end{abstract}

Journal of Molecular Endocrinology (2005) 35, 257-267

\section{Introduction}

Estrogens control the development, differentiation and functioning of male and female reproductive organs. They also exhibit pleiotropic effects on non reproductive functions such as metabolism of bone, adipose or hepatic tissues, neuroendocrine and cardiovascular functions. Numerous reports suggest a role for estrogens in fetal and adult brain (Toran-Allerand et al. 1999, Wise et al. 2001, McEwen 2002, Maggi et al. 2004). The development and organization of neural circuits controlling a large spectrum of sexual functions is permanently influenced by gonadal steroids (McEwen 2002). Thus, estrogens have been reported to be involved in several aspects of neuronal differentiation such as neurite outgrowth, arborization and synapse formation. Estrogens also exert neuroprotective effects. Experiments carried out in animal models of focal ischemia demonstrate that estrogenic impregnation markedly reduces the incidence and importance of stroke events whereas some retrospective epidemiological studies suggest that substitutive hormonal therapy may reduce or delay the occurrence of Alzheimer's disease in elderly women (Wise 2003). In vitro, estrogens reduce cell death following different neuronal insults, including serum deprivation, glutathione depletion and treatment with L-glutamate, and decrease the synthesis and toxicity of amyloid- $\beta$ peptides in neuronal targets (Behl 2002).

Neuroprotective or differentiating effects of estrogens have been reported to be mediated, in part, by estrogen receptor alpha $(\mathrm{ER} \alpha)$, this receptor subtype being found in several brain structures such as the hypothalamus and hippocampus (Behl 2002). ER $\alpha$ is a ligand-inducible transcription factor that belongs to the nuclear receptor family. Like the other members of this family, this protein presents a modular structure which can be subdivided into six distinct regions, from $\mathrm{A}$ to $\mathrm{F}$ (Evans 1988, Beato 1989). The $\mathrm{C}$ and $\mathrm{E}$ domains are responsible for DNA and ligand binding respectively. The B domain contains a ligand-independent transactivation function, $\mathrm{AF}-1$, whereas a hormone-inducible transactivation function, $\mathrm{AF}-2$, is present in the hormone binding domain $(\mathrm{E})$.

Several data have recently emphasized the importance of the A/B domain in the cellular and physiological functions of ER $\alpha$. Some transgenic ER $\alpha-/-$ mice 
(ER $\alpha$-Neo KO mice), which do not express the wild-type $\mathrm{ER} \alpha$ but express an N-terminal A/B truncated form of the receptor (referred to as ER $\alpha 46$ ) present critical physiological deficiencies, especially regarding reproductive function, and are thus infertile (Couse et al. 1995, Pendaries et al. 2002). Full activity of the transactivation function, $\mathrm{AF}-1$, located in the $\mathrm{A} / \mathrm{B}$ domain is required for the estradiol-dependent proliferation of the ER $\alpha$ positive breast cancer cell line, MCF7 (Fujita et al. 2003). Moreover, the respective contributions that AF-1 and AF-2 make towards ER $\alpha$ activity have been demonstrated to vary in a cell differentiation stage-dependent manner (Mérot et al. 2004). Specifically, AF-1 is the dominant $\mathrm{AF}$ involved in $\mathrm{ER} \alpha$ transcriptional activity in differentiated cells, and this strongly suggests the importance of the N-terminal domains in ER $\alpha$ transcriptional activity in most estrogen target cell types.

Information is poor concerning differentiating or protective effects of ER $\alpha$ in the brain. Nevertheless, the $\mathrm{ER} \alpha$ subtype is a critical mechanistic link in mediating the protective effects of physiological levels of estradiol in brain injury (Dubal et al. 1999, 2001), because the deletion of $\mathrm{ER} \alpha$ by $\mathrm{ER} \alpha$ knock-out in mouse abolishes the protective actions of estradiol in different brain regions (Dubal et al. 2001).

Therefore, the aim of our study was to investigate the precise role of the A/B domain of $\mathrm{ER} \alpha$ in estrogenmediated neuronal functions, using the well characterized pheochromocytoma PG12 cell line. PG12 cells have a special place among the different in vitro neuronal models. Indeed, they have been extensively used for studying mechanisms of both neuronal differentiation and survival because of their ability to differentiate into sympathetic-like neurons and to extend neurite outgrowth when treated with nerve growth factor (NGF), and because of their ability to undergo cell death following serum and NGF withdrawal (Gollapudi \& Oblinger $1999 a, b)$ or following some oxidative shocks, such as depletion of glutathione (Le Foll \& Duval 2001). Besides, PG1 2 cells do not express endogenous ER $\alpha$ in their native state and this has allowed us to study directly the impact of different forms of ER $\alpha$ (full-length $\mathrm{ER} \alpha$ or truncated $\mathrm{ER} \alpha$ in the A/B domain) on the fate of PC12 cells after transient or stable transfections of the corresponding expression vectors. Using this approach, we demonstrated that ER $\alpha$-mediated effects of estrogens on the transcriptional activity of estrogen target reporter genes, on the NGF-induced neurite sprouting or on cell survival to oxidative stress require the $\mathrm{A} / \mathrm{B}$ domain of $\mathrm{ER} \alpha$.

\section{Materials and methods}

\section{Chemicals}

$17 \beta$-estradiol (17 $\beta \mathrm{E} 2), 17 \alpha$-estradiol (17 $\alpha \mathrm{E} 2)$, 4-hydroxytamoxifen (4-OHT), and buthionine sulfoximine (BSO) were purchased from Sigma (St Louis, MO, USA). ICI 182,780 and NGF were purchased from Tocris (Bristol, UK) and ICN (Irvine, CA, USA) respectively.

\section{Cell culture}

Wild-type PG12 cells were grown routinely at $37^{\circ} \mathrm{C}$ in $5 \% \mathrm{CO}_{2}$ atmosphere in Dulbecco's modified Eagle's medium with F12 (DMEM/F12; Sigma) supplemented with 10\% fetal calf serum (FCS; Sigma-Aldrich), 5\% horse serum (HS; Life Technologies, Pontoise, France), $1 \%$ of a solution containing $10 \mu \mathrm{g} / \mathrm{ml}$ penicillin $\mathrm{G}$, $10 \mathrm{mg} / \mathrm{ml}$ streptomycin, and $25 \mu \mathrm{g} / \mathrm{ml}$ amphotericin B in $0.9 \% \mathrm{NaCl}$ and $2 \mathrm{mM}$ L-glutamine (Sigma).

\section{Transcriptional activity of ER in PC12 cells and the activity of AFs}

PC12 cells were transfected with FuGEN 6 (Roche). One hour prior to transfection, the routine medium was replaced with phenol red-free DMEM-F12 containing $1 \%$ charcoal-stripped HS. Transfection was carried out with a DNA mixture composed of the expression vector pSG5, pSG hER $\alpha$ or pSG hER $\alpha \mathrm{CF}$ (truncated ER) (Green et al. 1988, Flouriot et al. 2000), the reporter gene, and the CMV- $\beta \mathrm{Gal}$ internal control (respectively 200, 400 and $400 \mathrm{ng}$ per well).

The transcriptional activity of ER $\alpha$ was determined using two luciferase reporter plasmids: (i) an artificial promoter containing an estrogen responsive element (ERE) upstream of the thymidine kinase (TK) promoter (ERE-TK-LUG) (Flouriot et al. 2000) or (ii) the promoter of the human complement C3 (C3-LUG) (Métivier et al. 2001), responsive to 4-OHT (Norris et al. 1997). The luciferase activity was determined after $36 \mathrm{~h}$ transient transfection (Métivier et al. 2001) and was normalized with $\beta$-galactosidase activities.

\section{Generation of stable transfectants expressing the full-length ER $\alpha$ or the truncated isoform ER $\alpha$ CF}

Wild-type PC12 cells were grown to $50 \%$ confluence in phenol red-free DMEM/F12 containing 7.5\% charcoal-stripped FCS and 2.5\% charcoal-stripped HS and antibiotics (as above). They were stably transfected with FuGEN6 (Roche) using $1 \mu \mathrm{g}$ of each expression vector. The expression vectors pCR3.1 ER $\alpha$ and pCR3.1 ER $\alpha \mathrm{CF}$ were obtained by cloning respectively the full length ER $\alpha$ coding region and the ER $\alpha$ coding region from +727 to +2030 of the human sequence (Flouriot et al. 2000) into the BamHI site of the parental expression vector pCR3.1. Stably transfected PG12 cells were selected by the addition of G418 (a neomycin analog, $800 \mu \mathrm{g} / \mathrm{ml}$ ) to the media for 
1 month and were routinely maintained in phenol red-free DMEM containing 7.5\% charcoal-stripped FCS and 2.5\% charcoal-stripped HS, antibiotics (as above) and G418 (400 $\mu \mathrm{g} / \mathrm{ml})$.

\section{Western blot analysis}

Whole cell extracts from different PG12 subclones were fractionated on polyacrylamide-SDS gels and transferred on nitrocellulose membranes (Amersham, Bucks, UK). The blots were then blocked with a $5 \%$ milk PBS/Tween $0.01 \%$, and incubated for $90 \mathrm{~min}$ with a rabbit polyclonal anti-human ER $\alpha$ (HC-20; TEBU, Le Perray en Yvelines, France; 1/500 dilution). After washing, the blots were incubated with a peroxidase-conjugated goat anti-rabbit $\mathrm{IgG}$ for $1 \mathrm{~h}$ (TEBU; 1/5000 dilution). Secondary antibodies were detected using the SuperSignal West Dura kit (Pierce, Rockford, IL, USA).

\section{Cell death and neuroprotective effects of sex steroids}

The neuroprotective actions of steroids (17 $\beta \mathrm{E} 2,17 \alpha \mathrm{E} 2)$ were investigated following cell death caused by a buthionine sulfoximine (BSO)-induced depletion of intracellular glutathione (Froissard et al. 1997, Le Foll \& Duval 2001). Cells were incubated for $24 \mathrm{~h}$ with steroids and then treated with $300 \mu \mathrm{M}$ BSO for $24 \mathrm{~h}$. Dead cells were counted in the culture supernatant using the trypan blue exclusion procedure. In separate experiments, $17 \beta \mathrm{E} 2$ was given at the same time as treatment with BSO (lack of a pretreatment) or $24 \mathrm{~h}$ before BSO in association with the estrogen antagonist ICI 182,780 .

The amount of intracellular glutathione (reduced glutathione (GSG)+GSSG oxidized glutathione) was measured using the method of Tietze (1969). The protein concentration was determined using the BCA protein assay kit (Pierce).

\section{Cell differentiation}

Cells $\left(4 \times 10^{3}\right.$ cells $\left./ \mathrm{cm}^{2}\right)$ were plated in Petri dishes, in phenol red-free DMEM/F12 containing 1\% inactived HS and antibiotics (as above). Twenty-four hours after seeding, the media were replaced and a recombinant NGF $(5 \mathrm{ng} / \mathrm{ml}$ ) was added for 48 or $96 \mathrm{~h}$. Cells were scored as differentiated or undifferentiated cells.

\section{Statistical analysis}

Comparisons used ANOVA, followed by a post hoc analysis (Fisher test) of individual group differences.
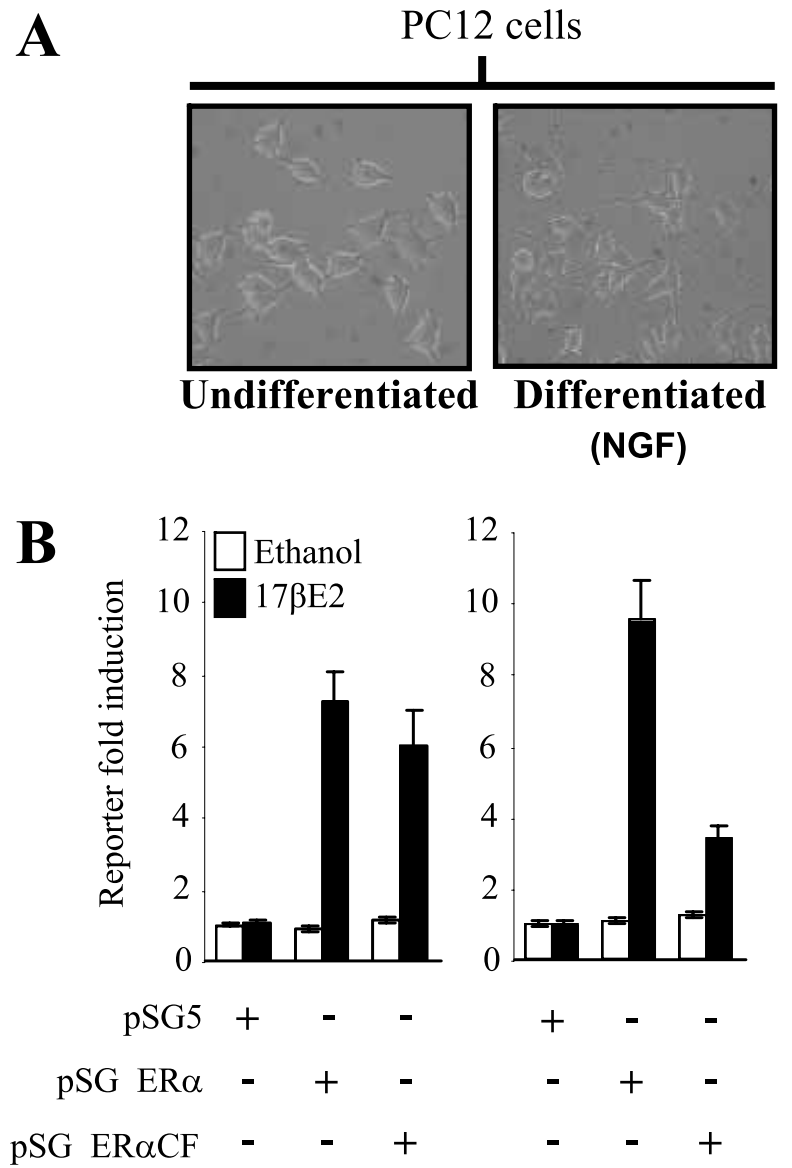

Figure 1 Transcriptional activity of ER $\alpha$ in relation to the differentiation stage of PC12 cells. Undifferentiated and differentiated PC12 cells (primed with $5 \mathrm{ng} / \mathrm{ml}$ NGF) were transiently transfected with the expression vectors pSG5 (control), pSG ER $\alpha$ (full length ER) and pSG ER $\alpha$ CF (truncated $\mathrm{ER})$. Cells were then treated with $10 \mathrm{nM} 17 \beta \mathrm{E} 2$ or ethanol (control). The transcriptional activity was determined using an ERE-TK synthetic estrogen-sensitive promoter coupled to luciferase (ERE-TK-LUC). Histograms show the means \pm S.E.M. of values normalized to the activity of the reporter gene measured in the presence of pSG5 without E2, obtained in at least three separate experiments.

\section{Results}

The mechanisms underlying the transcriptional activity of ERa in PC12 cells depend upon the differentiation status and the presence of the $A / B$ domain

The transcriptional activity of $\mathrm{ER} \alpha$ was studied, focusing on the role of the $\mathrm{A} / \mathrm{B}$ domain in differentiated and undifferentiated cells. Treatment with NGF leads to differentiation of PC12 cells into sympathetic-like neurons characterized by neurite outgrowths as shown in Fig. 1A. To assess the impact of the physiological stage of PC12 cells on ER $\alpha$ transcriptional activity, 
undifferentiated and differentiated cells were transiently co-transfected with the ERE-TK-LUC reporter gene and the expression vectors pSG5, pSG ER $\alpha$ (full length $\mathrm{ER} \alpha$ ) or pSG ER $\alpha \mathrm{CF}$ (truncated ER $\alpha$ ) and then treated or not with $17 \beta \mathrm{E} 2$. As expected, no estrogenic induction of the reporter gene was observed in either undifferentiated or differentiated cells transfected with the empty expression vector pSG5, confirming the absence of expression of endogenous ER. In undifferentiated cells, the activity of ER $\alpha \mathrm{CF}$ on the ERE-TK-LUG represented approximately $80 \%$ of that of the full-length receptor ERa (Fig. 1B). By contrast, the ERaCF transactivation activity represented only $30 \%$ of that of the full-length ER $\alpha$ after differentiation of PG12 cells (Fig. 1B). These data suggest that the transcriptional activity of $\mathrm{ER} \alpha$ depends mainly upon the A/B domain in differentiated cells.

The full-length ER $\alpha$ contains two major transactivation functions, one located in the A/B domain (AF-1), the other in the $\mathrm{C}$-terminal part of the hormone binding domain (AF-2) (Parker 1995). Since ER $\alpha$ CF is devoid of the $\mathrm{A} / \mathrm{B}$ domain, the above result could be related to changes in permissiveness of PC12 cells to both $\mathrm{AFs}$, the differentiation process favoring AF-1. To confirm this assumption, the transcriptional activity of the full-length $\mathrm{ER} \alpha$ was determined in the presence of the partial estrogen agonist 4-OHT. Indeed, the estrogenic activity of 4-OHT exclusively relies on the transactivation function, $\mathrm{AF}-1$, and is observed only in cells sensitive to this AF (Berry et al. 1990). Therefore, PG12 cells were transiently transfected with the expression vectors pSG5, pSG ER $\alpha$ or pSG ER $\alpha \mathrm{CF}$ and the C3-LUG reporter gene conducted by the human complement $\mathrm{C} 3$ promoter, a well characterized 4-OHT-responsive promoter (Norris et al. 1997). Treatment with 4-OHT weakly increased (fourfold induction) the transcriptional activity of the G3-LUG in undifferentiated PG12 cells transfected with pSG ER $\alpha$ (Fig. 2), confirming the weak permissiveness of these cells to AF-1. In contrast, in differentiated cells transfected with pSG ER $\alpha$, 4-OHT strongly potentiated the transcriptional activity of the reporter gene (15-fold induction). As expected, 4-OHT had no effects in PC12 cells transfected with pSG $\mathrm{ER} \alpha \mathrm{CF}$. These data demonstrate that the differentiation of PC12 into sympathetic-like neurons changes the relative contribution that both $\mathrm{AFs}$ exert on transcriptional activity by increasing cell sensitivity to AF-1.

\section{An increase by $17 \beta E 2$ of the NGF-induced neurite outgrowth is observed in PC12 cells stably transfected with $E R \alpha$ and requires the presence of the $A / B$ domain}

Previous studies have reported an estrogenic potentiation of NGF-induced neurite outgrowths in PG12 cells stably expressing ER $\alpha$ (Gollapudi \& Oblinger 2001).

\section{Undifferentiated Differentiated (NGF)}
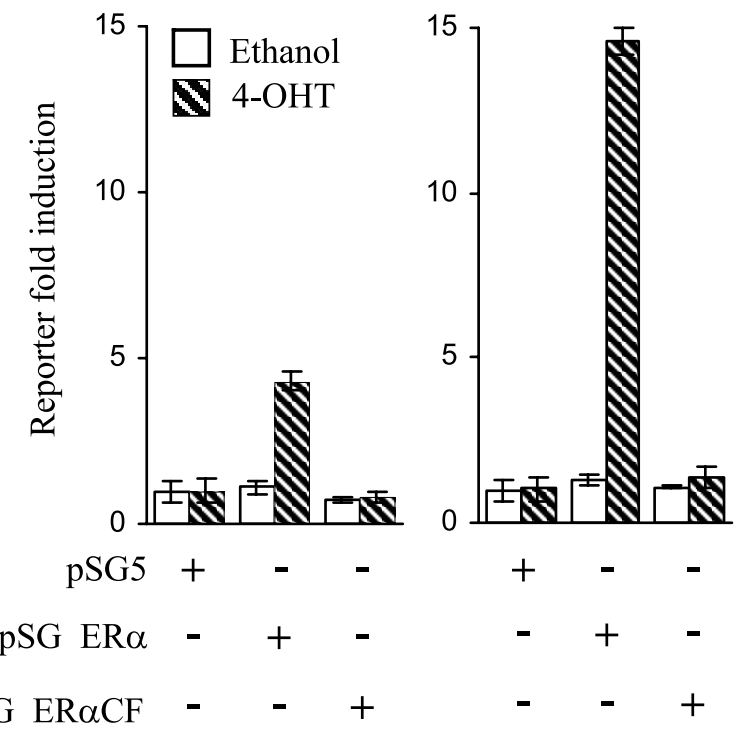

Figure 2 Transcriptional activity of ER $\alpha$ : relation with differentiation and contribution of the AF-1 function. Undifferentiated and differentiated PC12 cells (primed with $5 \mathrm{ng} / \mathrm{ml}$ NGF) were transiently transfected with the expression vectors pSG5 (control), pSG ER $\alpha$ (full length $E R$ ) and pSG $\mathrm{ER} \alpha \mathrm{CF}$ (truncated ER). Cells were then treated with $1 \mu \mathrm{M}$ 4-hydroxytamoxifen (4-OHT) or ethanol (control). The transcriptional activity was determined using the human complement C3 promoter coupled to luciferase (hC3-LUC) as a reporter gene. Histograms show the means \pm S.E.M. of values normalized to the activity of the reporter gene measured in the presence of pSG5 without E2, obtained in at least three separate experiments.

Therefore, the aim of the present experiment was to establish whether the A/B domain is involved in such an ER $\alpha$-dependent potentiation. PC12 cells were stably transfected with the expression vectors pCR $3 \cdot 1$, pCR3 1 $\mathrm{ER} \alpha$ or pCR3.1 ER $\alpha \mathrm{CF}$ and three subclones (PC12 control, PC12 ER $\alpha$ and PC12 ER $\alpha \mathrm{CF}$ ) were selected as described in the Materials and methods section. As expected, western blots revealed the expression of both full-length $\mathrm{ER} \alpha$ and $\mathrm{ER} \alpha \mathrm{CF}$ proteins in the corresponding subclones (C1, ER $\alpha-4, \mathrm{ER} \alpha \mathrm{CF}-1)$ (Fig. 3A). The absence of receptors in the PC12 cells transfected with the empty expression vector should be noted, confirming the ER $\alpha$ negative phenotype of parental PG12 cells. Moreover, no endogenous ER $\alpha$ or ER $\beta$ signals were found following PCR experiments using specific primers amplifying cDNAs from parental PG12 cells (data not shown). Addition of NGF $(5 \mathrm{ng} / \mathrm{ml})$ to the culture medium significantly increased neurite outgrowths in the three subclones PG12 control, PG12 ER $\alpha$ and PG12 $\mathrm{ER} \alpha \mathrm{CF}$, with some differences in the induction between clones (data not shown). This effect became apparent 
A

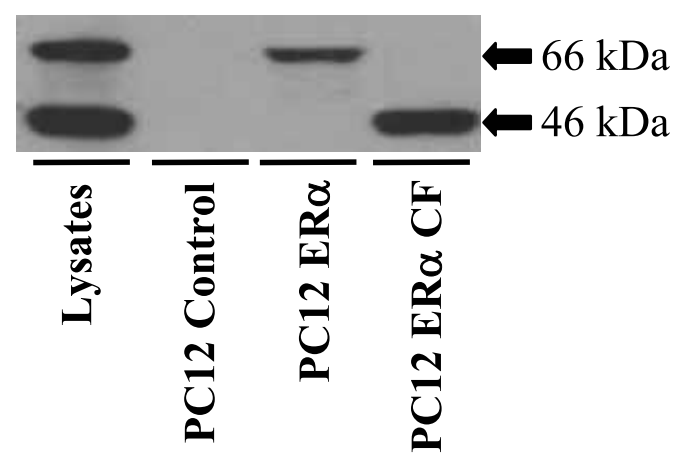

B
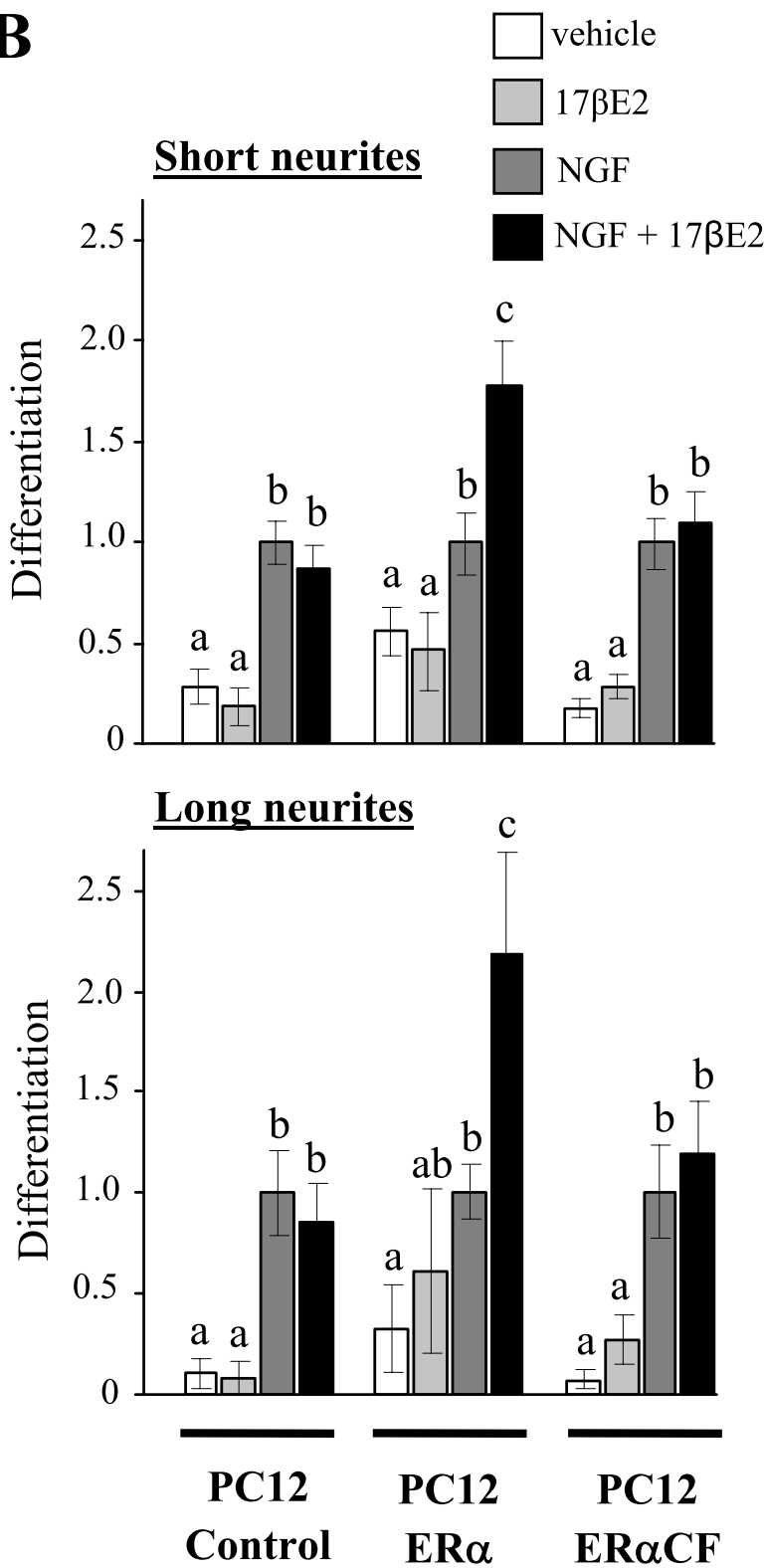

within $24 \mathrm{~h}$ of treatment for both criteria of neurite outgrowth (neurites greater than one or two cell bodies), and reached a plateau after 4 days (data not shown).

$17 \beta \mathrm{E} 2\left(10^{-8} \mathrm{M}\right)$ markedly potentiated the NGFinduced neurite extension in the PG12 ER $\alpha$ clone. After 2 days of treatment with NGF and estradiol, almost two times as many differentiated cells (cells having neurites greater than one or two cell bodies) were observed compared with treatment with NGF alone (Fig. 3B). This estradiol-induced potentiation of the effects of NGF in the PC12 ER $\alpha$ clone was not associated with changes in the density of the cell population (data not shown). By contrast, $17 \beta \mathrm{E} 2\left(10^{-8} \mathrm{M}\right)$ did not modify the NGFinduced neurite extension of PG12 ER $\alpha \mathrm{CF}$ and PG12 control clones. 17ßE2 did not modify neurite formation in the absence of NGF in any of the three clones. Similar data have been found using other control, ER $\alpha$ and $\mathrm{ER} \alpha \mathrm{CF}$ subclones (data not shown).

These results clearly demonstrated that the increase of NGF-induced neuronal differentiation by estrogen requires an $\mathrm{ER} \alpha$ presenting the $\mathrm{A} / \mathrm{B}$ domain.

\section{7קE2 offers protection from the toxic action of BSO by an ER $\alpha$-dependent mechanism involving the A/B domain}

Neuroprotective effects of estradiol have been reported in the literature, following different oxidative shocks. In the present report, a gradual death was caused by

Figure 3 (A) Generation of PC12 ER $\alpha$ and ER $\alpha$ CF stable transfectants. PC12 cells were stably transfected with the expression vectors pCR3.1, pCR3.1 ER $\alpha$ or pCR3.1 ER $\alpha \mathrm{CF}$. The respective harvested subconfluent subclones $\mathrm{PC} 12$ control (clone C1), PC12 ER $\alpha$ and PC12 ER $\alpha$ CF (clones ER $\alpha-4$ and $\mathrm{ER} \alpha \mathrm{CF}-1)$ were lyzed at $4{ }^{\circ} \mathrm{C}$ during $60 \mathrm{~min}$ in a RIPA lysis buffer (50 mM Tris- $\mathrm{HCl} \mathrm{pH} \mathrm{7.5,} 150 \mathrm{mM} \mathrm{NaCl}, 1 \% \mathrm{NP}-40$, $0.5 \%$ sodium deoxycholate, $0.1 \%$ SDS). Thirty micrograms whole cell extracts were fractionated on a polyacrylamide-SDS gel. Proteins of $66 \mathrm{kDa}$ (full length ER) and $46 \mathrm{kDa}$ (truncated ER) were revealed with a rabbit polyclonal IgG with an epitope mapping the carboxy-terminal region of the ER (HC-20). The in vitro expression of $\mathrm{ER} \alpha$ and $\mathrm{ER} \alpha \mathrm{CF}$ using the rabbit reticulocyte-coupled transcription/translation kit (TNT, Promega, Madison, WI, USA) acted as a positive control. (B) NGF-induced differentiation of PC12 control, PC12 ER $\alpha$ and $\mathrm{PC} 12 \mathrm{ER} \alpha \mathrm{CF}$ (truncated ER $\alpha$ ). Cells were treated by NGF $(5 \mathrm{ng} / \mathrm{ml})$ during two days with vehicle, $17 \beta \mathrm{E} 2$ only $(10 \mathrm{nM})$, NGF only $(5 \mathrm{ng} / \mathrm{ml})$ or NGF plus $17 \beta E 2$. Cells having at least a neurite greater than one (short neurites) or two (long neurites) cell bodies and total cells were counted for 20-30 fields (5-10 fields per dish in 3 separate experiments, at 200x magnification) in light microscopy. The ratios of 'cells with short or long neurites/total cells' were determined (means \pm S.E.M.) and used as criteria of differentiation after normalization with respective values of $\mathrm{PC} 12$ cells treated with NGF alone. Columns with different superscripts differ significantly $(P<0.05)$. A significant interaction between NGF and E2 was found by two-way ANOVA on day $2(P<0.05)$ for both the criteria (short and long neurites). 
treatment with BSO within $24 \mathrm{~h}$ (Froissard et al. 1997, Le Foll \& Duval 2001). As expected, BSO led to the death of almost $70-80 \%$ of cells after $24 \mathrm{~h}$ incubation (Fig. 4). The three clones (PG12 control, PG12 ER $\alpha$ and PC12 ER $\alpha \mathrm{CF}$ ) were equally sensitive to the toxicity of BSO (data not shown). Preincubation with $17 \beta E 2$ for $24 \mathrm{~h}$ before treatment with $\mathrm{BSO}$, in the physiological concentration range of $0 \cdot 1-10 \mathrm{nM}$, significantly increased the viability of $\mathrm{PC} 12$ cells expressing the full length ER $\alpha$ (Fig. 4A). Moreover, $1 \mathrm{nM} 17 \beta \mathrm{E} 2$ did not

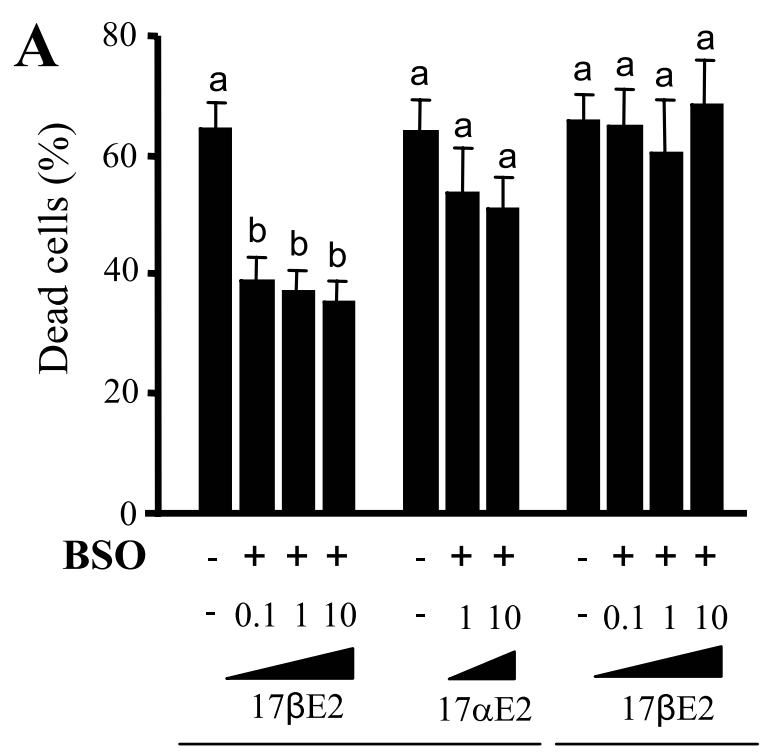

Preincubation $-24 \mathrm{~h}$ No preincubation
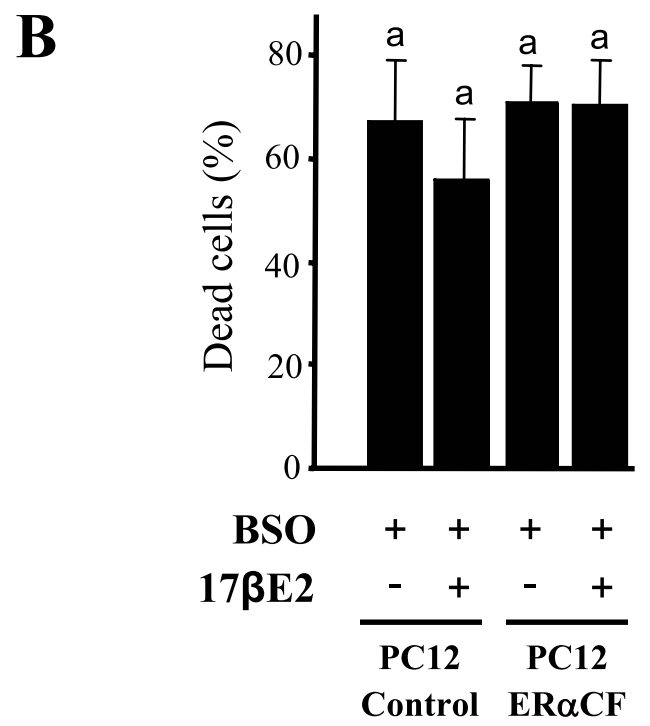

modify proliferation of ER $\alpha$ PC12 cells during a 6-7 days incubation period and failed to induce any changes in cell morphology during this period (data not shown). By contrast, 17ßE2 was unable to protect control cells and cells expressing ER $\alpha \mathrm{CF}$ from the oxidative shock (Fig. 4B). Altogether, our data suggest that $17 \beta \mathrm{E} 2$ is neuroprotective and requires an ER $\alpha$ presenting the $\mathrm{A} / \mathrm{B}$ domain. In addition, the ER $\alpha$-dependent neuroprotection by $17 \beta \mathrm{E} 2$ was not observed for the PC12 $\mathrm{ER} \alpha$ clone when (i) $17 \beta \mathrm{E} 2$ was given at the same time as BSO (i.e. without any preincubation with the steroid) (Fig. 4A), (ii) cells were pretreated with $17 \alpha \mathrm{E} 2$ $(1-100 \mathrm{nM})$, the transcriptional inactive isomer of $17 \beta \mathrm{E} 2$ (Fig. 4A), and (iii) 17ßE2 was associated with the estrogen antagonist ICI 182,780 (Fig. 5A). As the neuroprotective effects of estradiol require a period of pretreatment and are antagonized by ICI 182,780, we suggest that $\mathrm{ER} \alpha$-mediated alteration of gene expression is required to afford neuroprotection. Moreover, $1 \mathrm{nM}$ $17 \beta \mathrm{E} 2$ did not, by itself, change intracellular glutathione (GSH) content of PC12 cells expressing ER $\alpha$ and failed to block the GSH depletion (about 90\%) in the presence of BSO (Fig. 5B).

\section{Discussion}

Although estrogens exert a wide variety of actions on the developing and the adult brain, by regulating both neuronal differentiation and survival, their mechanisms of action are still unclear. The identification of many putative estrogen receptors in the brain has increased the complexity of our understanding of estrogen action (Toran-Allerand 2004). Among them, ER $\alpha$ has been reported to influence the development and the physiology of neurons. For instance, the development of the brain is associated with the perinatal expression of ER $\alpha$ in

Figure 4 (A) Neuroprotective effects of estradiol against buthionine sulfoximine (BSO). PC12 ER $\alpha$ (density adjusted to $8-10 \times 10^{3} \mathrm{cells} / \mathrm{cm}^{2}$ in 6 -well plates $(1.5 \mathrm{ml} /$ well $)$ in phenol red-free DMEM containing $10 \%$ charcoal-stripped FCS and $5 \%$ charcoal-stripped HS, antibiotics and $1 \mathrm{~g} / \mathrm{l}$ glucose) were treated with $300 \mu \mathrm{M}$ BSO (i) after $24 \mathrm{~h}$ of pre-incubation (preincubation-24 h) with 17ßE2 $(0.1,1,10 \mathrm{nM})$ or $17 \alpha \mathrm{E} 2(1$, $100 \mathrm{nM}$ ) or (ii) simultaneously (no preincubation) with $17 \beta \mathrm{E} 2$ $(0 \cdot 1,1,10 \mathrm{nM})$. Cell death was measured $24 \mathrm{~h}$ after the treatment with BSO and expressed as a percentage of the total cell population (adherent, viable and dead cells in the supernatant; means \pm S.E.M. of individual determinations for 3-8 distinct experiments). Columns with different superscripts differ significantly $(P<0.05)$. (B) Cell death of PC12 control or PC12 $\mathrm{ER} \alpha \mathrm{CF}$ (truncated ER $\alpha$ ) (for density and medium, see panel A) pretreated or not with $10 \mathrm{nM} 17 \beta \mathrm{E} 2$ for $24 \mathrm{~h}$. At this time, $300 \mu \mathrm{M}$ BSO were added for $24 \mathrm{~h}$. Cell death was expressed as a percentage of the total cell population (means \pm S.E.M.; $n=4-6)$. Columns with different superscripts differ significantly $(P<0.05)$. 
different brain structures such as the preoptic area or the hypothalamus (Gerlach et al. 1983). In the adult brain, estradiol protects against brain injury through blood flow-independent mechanisms (Dubal et al. 2001) and injury up-regulates the expression of ER $\alpha$ in regions that are protected by estradiol (Dubal et al. 1999). In mouse, the ER $\alpha$ knock-out, but not the $\operatorname{ER} \beta$ knock-out, abolishes the protective effects of the steroid (Dubal et al. 2001). Despite the huge amount of experimental evidence for a critical role of $\mathrm{ER} \alpha$ in the brain, the precise $\mathrm{ER} \alpha$-mediated mechanisms remain to be defined.
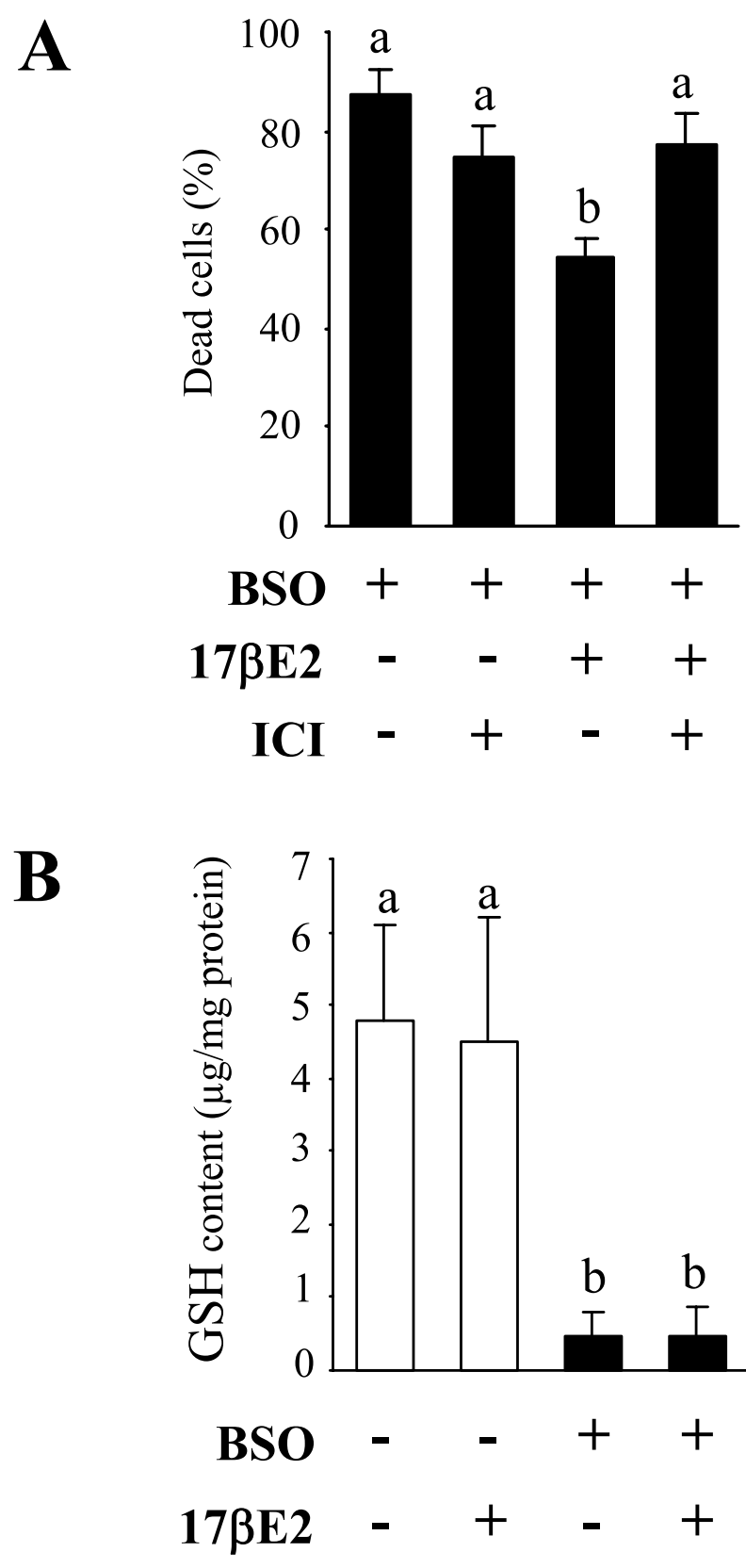

Several data have recently emphasized the importance of the $\mathrm{A} / \mathrm{B}$ domain in the functions of $\mathrm{ER} \alpha$. An insertional disruption of the $\mathrm{ER} \alpha$ gene in the first exon coding for the A/B domain (Couse et al. 1995, Pendaries et al. 2002) induces physiological deficiencies in the corresponding $\mathrm{ER}-/$ - mice (ER $\alpha-\mathrm{Neo} \mathrm{KO}$ mice), such as abolition of reproductive function. Although totally abolishing the production of the full length ER $\alpha$, the insertional disruption does not suppress the expression of a naturally occurring N-terminal A/B truncated form of the receptor, referred to as ERa46 (Flouriot et al. 2000). It is produced by an alternative splicing event which skips the first coding exon of the ER $\alpha$ gene, targeted by the disruptive insertion. As this form is devoid of the transactivation function AF-1 present in the $\mathrm{A} / \mathrm{B}$ domain of $\mathrm{ER} \alpha$, the phenotype of the ER $\alpha$-Neo KO mice could be viewed as being an ER $\alpha$ AF-1 knock-out. Conversely, this isoform is thought to be responsible for residual estrogen responsiveness such as the persistence of some degree of uterine hypertropy or the preservation of endothelial NO production in ER $\alpha$-Neo KO mice (Figtree et al. 2002, Pendaries et al. 2002). Therefore, the $\mathrm{ER} \alpha \mathrm{A} / \mathrm{B}$ domain appears to be dispensable to mediate some ER $\alpha$ functions. Up to now, such an isoform of ER $\alpha$ has unfortunately not been detected in the brain of ER $\alpha$ wild-type or ER $\alpha-/$ - mice, making elusive the relative importance of the $\mathrm{A} / \mathrm{B}$ domain in ER $\alpha$-mediated effects in the brain.

The goal of this study was to determine the possible relevance of the $\mathrm{A} / \mathrm{B}$ domain of $\mathrm{ER} \alpha$ in some estradiol-mediated effects in the brain, such as neuronal differentiation and neuroprotection. To solve this problem, we have developed a cellular model in which $\mathrm{ER} \alpha$ can mediate both neurotropic and neuroprotective effects, focusing on the role of estrogens on neurite outgrowth and resistance to some oxidative stress of PC12 cells expressing the full-length ER $\alpha$. Estradiol markedly potentiates the NGF-induced neurite outgrowth of PG12 ER $\alpha$ cells. Such a marked enhancement of NGF-stimulated neurite outgrowth of ER $\alpha$ transfected PC12 cells by estradiol had previously been associated with a modulation of some cytoskeletal mRNAs, such as peripherin and $\alpha$-tubulin (Gollapudi \&

Figure 5 (A) Cell death of PC12 ER $\alpha$, preincubated for $24 \mathrm{~h}$ with $17 \beta \mathrm{E} 2(1 \mathrm{nM})$ in the presence or not of $\mathrm{ICl} 182,780(\mathrm{ICl}$; $100 \mathrm{nM}$ ) and then treated with BSO. Cell death was measured $24 \mathrm{~h}$ after BSO and expressed as a percentage of the total cell population (means \pm S.E.M. of individual determinations for 3-8 distinct experiments). Columns with different superscripts differ significantly $(P<0.05)$. (B) Content of glutathione $(\mathrm{GSH})$ in the $\mathrm{PC} 12 \mathrm{ER} \alpha$ clone. Cells were preincubated in the absence (control) or in the presence of $1 \mathrm{nM} 17 \beta \mathrm{E} 2$ for $24 \mathrm{~h}$. At this time, $300 \mu \mathrm{M}$ BSO or solvent were added for $6 \mathrm{~h}$. Results are expressed as $\mu \mathrm{g} \mathrm{GSH} / \mathrm{mg}$ protein (means \pm S.E.M.; $n=4-6$ ). Columns with different superscripts differ significantly $(P<0.05)$. 
Oblinger 2001). A physiological range (nanomolar concentrations) of $17 \beta \mathrm{E} 2$ protected PC12 cells expressing $\mathrm{ER} \alpha$ against the toxicity of $\mathrm{BSO}$, an irreversible specific inhibitor of $\gamma$-glutamylcysteine synthase (Griffith \& Meister 1979a) which causes deprivation of glutathione stores (Griffith \& Meister 1979b), but did not protect control cells. Altogether, our data verify that some neuroprotective effects of estradiol require ER $\alpha$ and could not be related to antioxidant properties of the steroid at high concentrations (micromolar range) with a hydroxyl group in the C3 position (Sugioka et al. 1987, Behl et al. 1997). Moreover, because neuroprotective effects of estradiol require a period of pretreatment and are reversed by ICI 182,780, we suggest that an $\mathrm{ER} \alpha$-mediated alteration of gene expression is required to afford neuroprotection, as previously reported in other models such as organotypic cortical explant cultures (Wilson et al. 2000). It has been suggested that a possible synergistic interaction between glutathione and E2 is involved in the neuroprotective potency of the steroid in the HT22 cell line exposed to the neurotoxic beta-amyloid peptide (Green et al. 1998). Such an hypothesis cannot be held here, because protection was observed in the HT22 cell line lacking functional ER and because neuroprotective effects of estrogens in the present report require ER $\alpha$. Moreover, because 17 $\beta \mathrm{E} 2$ does not restore the levels of glutathione following treatment with BSO, neuroprotection may involve mechanisms downstream of the synthesis of reactive oxygen species, such as activation of antiapoptotic pathways. Indeed, BSO is one of the major factors controlling the redox status of cells and suppresses glutathione peroxidase (Griffith \& Meister 1979b). It leads to a programmed cell death (Serghini et al. 1994, Higuchi \& Matsukawa 1999, Leon et al. 2003), apoptosis being associated with high molecular-weight DNA fragmentation (Higuchi \& Matsukawa 1999). Some antiapoptotic effects of estradiol in nigral dopaminergic neurons treated with BSO have already been reported to be mediated by transcription through an AP-1 site downstream from JNK and caspase-3 activation (Sawada et al. 2000). Such a mechanism cannot be considered here because neuroprotective effects of estrogens in dopaminergic neurons were observed after both $17 \alpha \mathrm{E} 2$ and $17 \beta \mathrm{E} 2$ and appeared to be mediated by ER $\beta$. Moreover, the neuroprotection by estradiol could not be attributable to a general steroid structure because testosterone or progesterone did not provide protection against $\mathrm{BSO}$ (data not shown).

The role of the $\mathrm{A} / \mathrm{B}$ domain in the differentiating and neuroprotective effects described above was studied using PG12 cells expressing a truncated ER $\alpha(\mathrm{ER} \alpha \mathrm{CF})$. We have demonstrated that the A/B domain of ER $\alpha$ is essential for mediating both the protective effects of estrogens against oxidative stress and the potentiation of NGF-induced differentiation.
Estradiol influences, in complex ways, the expression of numerous genes in multiple regions of the brain that are theoretically relevant to the effects of estradiol observed in PC12 cells expressing ER $\alpha$. For instance, estradiol modifies the expression of genes involved in the dendritic and axonal elongation such as GAP-43 or Tau (Ferreira \& Caceres 1991, Shughrue \& Dorsa 1993), in the balance of apoptosis and of survival such as $\mathrm{Bcl} 2$ or bcl-XL (Pike 1999, Zhao et al. 2004) or in the driving of the growth factor effects, like TrkA or p $75^{\text {NGFR }}$ (Sohrabji et al. 1994, Toran-Allerand 1996). These ligand-activated mechanisms may involve a direct control of target gene transcription from both the ERE and various alternate response elements such as AP-1 motifs. Putative ERE found in target genes such as TrkA, BDNF, Bcl-2, Bcl-XL and p75 $5^{\text {NGFR }}$ support this idea (Sohrabji et al. 1994, 1995, Toran-Allerand 1996). As the A/B domain harbors the activation function AF-1, ER $\alpha$-mediated genomic effects seem to be relevant in the differentiating and neuroprotective effects of estradiol in PC12 ER $\alpha$ cells. Accordingly, we have recently reported that the transcriptional activity of ER $\alpha$ is essentially mediated by AF-1 in differentiated cells (Mérot et al. 2004). We thus demonstrated that P19 cells which transiently expressed ERaCF (but not P19 cells expressing ER $\alpha$ ) became transcriptionally inactive following a retinoic acid-induced differentiation into a neural phenotype. The same strategy has therefore been conducted here in PC12 cells to assess the relevance of $\mathrm{AF}-1$ in ER $\alpha$ transcriptional activity. An enhancement of the role of AF-1 in $\mathrm{ER} \alpha$ activity following differentiation is suggested in PC12 cells, as shown by the measurement of the agonistic activity of 4-OHT. As a result, it appeared that $\mathrm{ER} \alpha \mathrm{CF}$ was much less efficient than $\mathrm{ER} \alpha$ in the activation of transcription in differentiated cells. Nevertheless, unlike P19 cells, we observed a residual transcriptional activity of ER $\alpha \mathrm{CF}$. Because the percentage of differentiated cells after $48 \mathrm{~h}$ of NGF exposure does not go beyond $60 \%$, we suppose that a mixing of transfected differentiated and undifferentiated PC12 cells in culture may, in part, mask the strict AF-1 cell context of differentiated cells. A cross-talk between ER $\alpha$ and NGF signaling could explain the increase in AF-1 activity of differentiated PC12 cells. Indeed, like epidermal growth factor or insulin-like growth factor-I, NGF activates extracellular signal-regulated protein kinase (ERK), resulting in the direct phosphorylation of ER $\alpha$ on serine 118 (a phosphorylation site of the $\mathrm{B}$ domain), promoting an AF-1-dependent transcriptional activity (Ho \& Liao 2002). However, the agonist activity of 4-OHT does not seem to be linked to the phosphorylation status of serine 118 (data not shown), suggesting that the enhancement of $\mathrm{AF}-1$ in $\mathrm{ER} \alpha$ transcriptional activity is likely to be a combination of several mechanisms involving specific cofactor expression and post-traductional modifications. 
Besides direct regulation of gene transcription, evidence has clearly emerged that ER $\alpha$ can regulate gene expression by signaling pathways initiated outside the nucleus (Abraham et al. 2004, Edwards 2005). These so-called nongenomic effects include activation of cell signaling molecules such as protein kinases. In several models, the neurotropic and neuroprotective effects of estrogen have been linked to a rapid stimulation of the mitogen activated protein kinase (MAPK) pathway and/or the phosphoinositol 3-kinase (PI3K) pathway (Singer et al. 1999, Kuroki et al. 2001, Zhang et al. 2001, Fitzpatrick et al. 2002, Mize et al. 2003, Dominguez et al. 2004). Such rapid nongenomic effects could potentially promote differentiating and protective effects of estrogens in PG12 ER $\alpha$ cells. Numerous studies focusing on the molecular mechanism underlying estradioldependent activation of Ras/MEK/ERK and/or PI3K/Akt pathways have identified c-src as a critical upstream effector in cortical explants, osteoclasts and breast cancer cell lines (Migliaccio et al. 1998, Kousteni et al. 2001, Nethrapalli et al. 2001). Functional interactions between c-src and the E domain of ER $\alpha$ are able to promote estradiol-dependent c-src activation. Thus, the $\mathrm{E}$ domain of $\mathrm{ER} \alpha$ was sufficient to mediate estradiol protection against apoptosis in osteoclasts, osteocytes, embryonic fibroblasts and HeLa cells via activation of the src/Ras/MEK/ERK pathway (Kousteni et al. 2001). Such a mechanism, involving the $\mathrm{E}$ domain of $\mathrm{ER} \alpha$, might confer an estradiol-induced neuroprotection in PG12 ER $\alpha$ CF. This is not true in the present study. Importantly, no ER $\alpha$-dependent activation of ERK1/2 was detected in ER $\alpha$ and $\mathrm{ER} \alpha \mathrm{CF}$ PG12 cells (data not shown). Nevertheless, several intracellular signaling pathways can be activated by E2/ER $\alpha$ and the role of extranuclear ER $\alpha$-initiated mechanisms cannot be ruled out in the present study. Furthermore, both nuclear and extranuclear ER $\alpha$ signaling may converge to afford the neuroprotective effects of estradiol, as suggested by the study of Mize et al. (2003). Indeed, activation of the MAPK cascade by estradiol has been reported to be involved in the protection of different HT22 ER $\alpha$ clones from oxidative stress (Singer et al. 1999, Mize et al. 2003). This estradiol-induced neuroprotection was observed in an HT22 ER $\alpha$ clone, but also in an HT22 clone expressing an ER $\alpha$ modified in its ERE-binding domain (HE27) (Mize et al. 2003). Nevertheless, the neuroprotection in the HE27 clone was moderate when compared with the neuroprotection afforded by estradiol in the ER $\alpha$ clone, despite a similar ER $\alpha$-dependent activation of ERK. This suggests that both activation of the MAPK cascade and EREdependent transcriptional regulation promote ER $\alpha$ mediated neuroprotection by estradiol in this model. Such an interplay between nongenomic and genomic pathways has been evidenced in the neuroblastoma cell line SK-N-BE2C transiently transfected with ER $\alpha$ and treated with estradiol, in which early membrane estrogenic events potentiated the delayed transcriptional response of ER $\alpha$ (Vasudevan et al. 2001).

In conclusion, we provide evidence for a critical role of the $\mathrm{A} / \mathrm{B}$ domain in both differentiating and protective effects of estradiol in PG12 cells. Nevertheless, multifactorial and inter-connected ER $\alpha$-mediated effects may promote tropic and/or protective effects in the brain, depending on the cell context and the duration of estradiol impregnation. Further experiments in PC12 cells will focus on this point and on the characterization of some signaling pathways involved in the differentiating and neuroprotective effects of estradiol.

\section{Acknowledgements}

This work was supported by the Ligue Contre le Cancer and the Association pour la Recherche contre le Cancer (ARC). The authors declare that there is no conflict of interest that would prejudice the impartiality of this scientific work.

\section{References}

Abraham IM, Todman MG, Korach KS \& Herbison AE 2004 Critical in vivo roles for classical estrogen receptors in rapid estrogen actions on intracellular signaling in mouse brain. Endocrinology 145 3055-3061.

Beato M 1989 Gene regulation by steroid hormones. Cell $\mathbf{5 6}$ 335-344.

Behl C 2002 Oestrogen as a neuroprotective hormone. Nature Reviews Neuroscience 3 433-442.

Behl C, Skutella T, Lezoualc'h F, Post A, Widmann M, Newton CJ \& Holsboer F 1997 Neuroprotection against oxidative stress by estrogens: structure-activity relationship. Molecular Pharmacology $\mathbf{5 1}$ 535-541.

Berry M, Metzger D \& Chambon P 1990 Role of the two activating domains of the estrogen receptor in the cell-type and promoter-context dependent agonistic activity of the anti-estrogen 4-hydroxytamoxifen. EMBO foumal $92811-2818$.

Couse JF, Curtis SW, Washburn TF, Lindzey J, Golding TS, Lubahn D, Smithies O \& Korach KS 1995 Analysis of transcription and estrogen insensitivity in the female mouse after targeted disruption of the estrogen receptor gene. Molecular Endocrinology 9 1441-1454.

Dominguez R, Jalali C \& De Lacalle S. 2004 Morphological effects of estrogen on cholinergic neurons in vitro involves activation of extracellular signal-regulated kinases. Fournal of Neuroscience $\mathbf{2 4}$ 982-990.

Dubal DB, Shughrue PJ, Wilson ME, Merchenthaler I \& Wise PM 1999 Estradiol modulates bcl-2 in cerebral ischemia: a potential role for estrogen receptors. Journal of Neuroscience 19 6385-6393.

Dubal DB, Zhu H, Yu J, Rau SW, Shughrue PJ, Merchenthaler I, Kindy MS \& Wise PM 2001 Estrogen receptor alpha, not beta, is a critical link in estradiol-mediated protection against brain injury. PNAS 98 1952-1957.

Edwards DP 2005 Regulation of signal transduction pathway by estrogen and progesterone. Annual Review of Physiology 67 335-376.

Evans RM 1988 The steroid and thyroid hormone receptor superfamily. Science 240 889-895. 
Ferreira A \& Caceres A 1991 Estrogen-enhanced neurite growth: evidence for a selective induction of Tau and stable microtubules. Fournal of Neuroscience 11 392-400.

Figtree GA, McDonald D, Watkins H \& Channon KM 2002 Truncated estrogen receptor $\alpha 46-\mathrm{kDa}$ isoform in human endothelial cells; relation to acute activation of nitric oxide synthase. Circulation 107 120-126.

Fitzpatrick JL, Mize AL, Wade GB, Harris JA, Shapiro RA \& Dorsa DM 2002 Estrogen-mediated neuroprotection against $\beta$-amyloid toxicity requires expression of estrogen receptor $\alpha$ or $\beta$ and activation of the MAPK pathway. Fournal of Neurochemistry $\mathbf{8 2}$ $674-682$.

Flouriot G, Brand H, Denger S, Métivier R, Kos M, Reid G, Sonntag-Buck V \& Gannon F 2000 Identification of a new isoform of the human estrogen receptor-alpha (hER- $\alpha$ ) that is encoded by distinct transcripts and that is able to repress hER- $\alpha$ activation function 1. EMBO Fournal 19 4688-4700.

Froissard P, Monrocq H \& Duval D 1997 Glutamate-induced programmed cell death in neuronal-like PG12 cells is mediated through an inhibition of glutathione metabolism. European fournal of Pharmacology 326 93-99.

Fujita T, Kobayashi Y, Wada O, Tateishi Y, Kitada L, Yamamoto Y, Takashima H, Murayama A, Yano T, Baba T, Kawabe Y \& Yanagisawa J 2003 Full activation of estrogen receptor alpha activation function-1 induces proliferation of breast cancer cells. Fournal of Biological Chemistry 278 26704-26714.

Gerlach JL, McEwen BS, Toran-Allerand CD \& Friedman WJ 1983 Perinatal development of estrogen receptors in mouse brain assessed by radioautography, nuclear isolation and receptor assay. Brain Research 313 7-18.

Gollapudi L \& Oblinger MM 1999a Stable transfection of PC12 cells with estrogen receptor $(\mathrm{ER} \alpha)$ : protective effects of estrogen on cell survival after serum deprivation. Fournal of Neuroscience Research $\mathbf{5 6}$ 99-108.

Gollapudi L \& Oblinger MM $1999 b$ Estrogen and NGF synergistically protect terminally differentiated, ER $\alpha$-transfected PG12 cells from apoptosis. Fournal of Neuroscience Research $\mathbf{5 6}$ $471-481$

Gollapudi L \& Oblinger MM 2001 Estrogen effects on neurite outgrowth and cytoskeletal gene expression in ER $\alpha$-transfected PC12 cell lines. Experimental Neurology 171 308-316.

Green PS, Gridley KE \& Simpkins JW 1998 Nuclear estrogen receptor-independent neuroprotection by estratrienes: a novel interaction with glutathione. Neuroscience 84 7-10.

Green S, Kumar V, Theulaz I, Wahli W \& Chambon P 1988 The N-terminal DNA-binding 'zinc finger' of the estrogen and glucocorticoid receptors determines target gene specificity. EMBO fournal 7 3037-3044.

Griffith OW \& Meister A 1979a Potent and specific inhibition of glutathione synthesis by buthionine sulfoximine (S-n-butylhomocysteine sulfoximine). Foumal of Biological Chemistry 254 7558-7560.

Griffith OW \& Meister A $1979 b$ Glutathione: interorgan translocation, turnover, and metabolism. PNAS 76 5606-5610.

Higuchi Y \& Matsukawa S 1999 Glutathione depletion induces giant DNA and high-molecular-weight DNA fragmentation associated with apoptosis through lipid peroxidation and protein kinase $\mathrm{C}$ activation in C6 glioma cells. Archives of Biochemistry and Biophysics $36333-42$.

Ho KJ \& Liao JK 2002 Non-nuclear actions of estrogen: new targets for prevention and treatment of cardiovascular disease. Molecular Interventions 2 219-228.

Kousteni S, Bellido T, Plotkin LI, O'Brien CA, Bodenner DL, Han L, Han K, DiGregorio GB, Katzenellenbogen JA, Katzenellenbogen BS, Roberson PK, Weinstein RS, Jilka RL \& Manolagas SC 2001 Nongenotropic, sex-nonspecific signaling through the estrogen or androgen receptors: dissociation from transcriptional activity. Cell $\mathbf{1 0 4}$ 719-730.
Kuroki Y, Fukushima K, Kanda Y, Mizuno K \& Watanabe Y 2001 Neuroprotection by estrogen via extracellular signal-regulated kinase against quinolinic acid-induced cell death in the rat hippocampus. European Fournal of Neuroscience 13 472-476.

Le Foll I \& Duval D 2001 Programmed cell death induced by glutathione depletion in PC12 cells is blocked by inhibitors of 12 lipoxygenase, but does not appear to be mediated through the formation of 12 HETE derivatives. Free Radical Biology and Medicine 30 793-802.

Leon A, Le Foll I, Charriault-Marlangue C, Leprince J, Vaudry H, Gabriel C \& Duval D 2003 The level of heme oxygenase does not obligatorily reflect the sensitivity of PC12 cells to an oxidative shock induced by glutathione depletion. Fournal of Neurochemistry $\mathbf{8 4}$ 459-470.

McEwen BS 2002 Estrogen actions throughout the brain. Recent Progress in Hormone Research 57 357-384.

Maggi A, Ciana P, Belcredito S \& Vegeto E 2004 Estrogens in the nervous system: mechanisms and nonreproductive functions. Annual Review of Physiology 66 291-313.

Mérot Y, Métivier R, Penot G, Manu D, Saligaut C, Gannon F, Pakdel F, Kah O \& Flouriot G 2004 The relative contribution exerted by AF-1 and AF-2 transactivation functions in estrogen receptor alpha $(\mathrm{ER} \alpha)$ transcriptional activity depends upon the differentiation stage of the cell. Fournal of Biological Chemistry 279 26184-26191.

Métivier R, Penot G, Flouriot G \& Pakdel F 2001 Synergism between ERalpha transactivation function 1 (AF-1) and AF-2 mediated by steroid receptor coactivator protein-1: requirement for the AF-1 alpha-helical core and for a direct interaction between the N- and C-terminal domains. Molecular Endocrinology 15 1953-1970.

Migliaccio A, Piccolo D, Castoria G, Di Domenico M, Bilancio A, Lombardi M, Gong W, Beato M \& Auricchio F 1998 Activation of the Src/p21 ras/Erk pathway by progesterone receptor via cross-talk with estrogen receptor. EMBO fournal 17 2008-2018.

Mize AL, Shapiro RA \& Dorsa DM 2003 Estrogen receptor-mediated neuroprotection from oxidative stress requires activation of the mitogen-activated protein kinase pathway. Endocrinology 144 306-312.

Nethrapalli IS, Singh M, Guan X, Guo Q Lubahn DB, Korach KS \& Toran-Allerand CD 2001 Estradiol (E2) elicits SRC phosphorylation in the mouse neocortex: the initial event in E2 activation of the MAPK cascade? Endocrinology 142 5145-5148.

Norris JD, Fan D, Kerner SA \& McDonnell DP 1997 Identification of a third autonomous activation domain within the human estrogen receptor. Molecular Endocrinology 11 747-754.

Parker MG 1995 Structure and function of estrogen receptors. Vitamins and Hormones 51 267-287.

Pendaries C, Darblade B, Rochaix P, Krust A, Chambon P, Korach KS, Bayard F \& Arnal JF 2002 The AF-1 activation-function of ERalpha may be dispensable to mediate the effects of estradiol on endothelial NO production in mice. PNAS 99 2205-2210.

Pike CJ 1999 Estrogen modulates neuronal Bcl-xL expression and beta-amyloid-induced apoptosis: relevance to Alzheimer's disease. Fournal of Neurochemistry 72 1552-1563.

Sawada H, Ibi M, Kihara T, Urushitani M, Honda K, Nakanishi M, Akaike A \& Shimohama S 2000 Mechanisms of antiapoptotic effects of estrogens in nigral dopaminergic neurons. FASEB Foumal 14 1202-1214.

Serghini R, Froissard P, Sola B \& Duval D 1994 Cycloheximide and actinomycin D block the toxic effect of glutamic acid on PC12 cells. Neuroreport 6 29-32.

Shughrue PJ \& Dorsa DM 1993 Estrogen modulates the growth-associated protein GAP-43 (neuromodulin) mRNA in the rat preoptic area and basal hypothalamus. Neuroendocrinology $\mathbf{5 7}$ 439-447.

Singer CA, Figueroa-Masot XA, Batchelor RH \& Dorsa DM 1999 The mitogen-activated protein kinase pathway mediates estrogen 
neuroprotection after glutamate toxicity in primary cortical neurons. Fournal of Neuroscience 19 2455-2463.

Sohrabji F, Greene LA, Miranda RC \& Toran-Allerand CD 1994 Reciprocal regulation of estrogen and NGF receptors by their ligands in PC12 cells. Journal of Neurobiology 25 974-988.

Sohrabji F, Miranda RC \& Toran-Allerand CD 1995 Identification of a putative estrogen response element in the gene encoding brain-derived neurotrophic factor. PNAS 92 11110-11114.

Sugioka K, Shimosegawa Y \& Nakano M 1987 Estrogens as natural antioxidants of membrane phospholipid peroxidation. FEBS Letters $21037-39$.

Tietze F 1969 Enzymatic method for quantitative determination of total and oxidized glutathione. Analytical Biochemistry 27 507-522.

Toran-Allerand CD 1996 Mechanisms of estrogen action during neural development: mediation by interactions with the neurotrophins and their receptors? Fournal of Steroid Biochemistry and Molecular Biology 56 169-178.

Toran-Allerand CD 2004 A plethora of estrogen receptors in the brain: where will it end? Endocrinology 145 1069-1074.

Toran-Allerand CD, Singh M \& Setalo G Jr 1999 Novel mechanisms of estrogen action in the brain: new players in an old story. Frontiers in Neuroendocrinology 20 97-121.
Vasudevan N, Kow LM \& Pfaff DW 2001 Early membrane estrogenic effects required for full expression of slower genomic actions in a nerve cell line. PNAS 98 12267-12271.

Wilson ME, Dubal DB \& Wise PM 2000 Estradiol protects against injury-induced cell death in cortical explant cultures: a role for estrogen receptors. Brain Research 873 235-242.

Wise PM 2003 Estrogens: protective or risk factors in brain function? Progress in Neurobiology 69 181-191.

Wise PM, Dubal DB, Wilson ME, Rau SW \& Liu Y 2001 Estrogens: trophic and protective factors in the adult brain. Frontiers in Neuroendocrinology 22 33-66.

Zhang L, Rubinow DR, Xaing G, Li BS, Chang YH, Maric D, Barker JL \& Ma W 2001 Estrogen protects against beta-amyloid-induced neurotoxicity in rat hippocampal neurons by activation of Akt. Neuroreport 12 1919-1923.

Zhao L, Wu TW \& Brinton RD 2004 Estrogen receptor subtypes alpha and beta contribute to neuroprotection and increased Bcl-2 expression in primary hippocampal neurons. Brain Research 1010 22-34.

Received 27 May 2005

Accepted 20 June 2005 